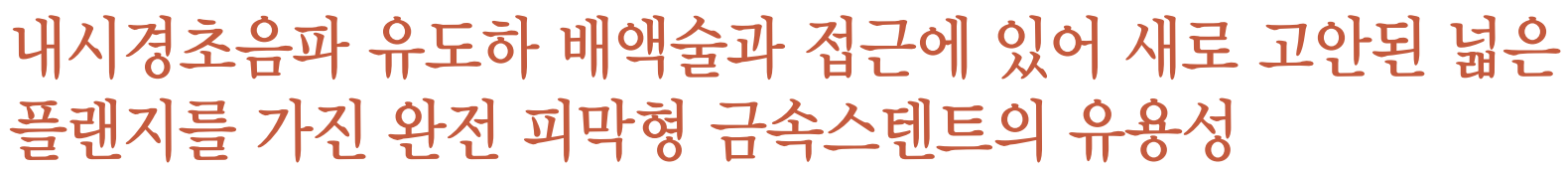

건국대학교 의학전문대학원 건국대학교병원 내과 소화기병센터

이태윤 · 천영국 · 심찬섭

\title{
A Newly Designed, Fully Covered, Metal Stent with Wide Flanges for EUS-Guided Drainage and Access
}

\author{
Tae Yoon Lee, Young Koog Cheon, Chan Sup Shim \\ Digestive Disease Center, Department of Internal Medicine, Konkuk University Medical Center, Konkuk University School of Medicine, \\ Seoul, Korea
}

Background/Aims: Endoscopic ultrasound (EUS)-guided drainage of pancreatic fluid collections is a useful and effective procedure. One of the main limitations is the lack of devices tailored specifically for this technique. This study aims to evaluate a newly developed, fully covered, biflanged metal stent customized for EUS-guided transenteric drainage.

Methods: We enrolled one dog in an animal study and six patients with pancreatic fluid (five with pancreatic pseudocysts and one with pancreatic walled-off necrosis) in a clinical study. We performed EUS-guided drainage of the pancreatic fluid or gallbladder using a newly developed metal stent. Study outcomes were technical and clinical success, adverse events, and stent removability.

Results: In the animal study, the stent was placed successfully in the gallbladder via the EUS-guided transduodenal approach without complication. The cholecystoduodenal tract was intact on necropsy performed immediately after the procedure. The stents were inserted successfully and deployed in the six patients. There was no adverse event during or after the procedure.

Conclusions: EUS-guided transenteric drainage using a new fully covered, biflanged metal stent was technically feasible and was not associated with any serious adverse event. The tailored design of the flange at the end of the stent facilitated the effectiveness of the procedure.

$\begin{array}{lr}\text { Received } & \text { Apr. 9, } 2018 \\ \text { Revised } & \text { May 28, } 2018 \\ \text { Accepted } & \text { Jun. 13, } 2018\end{array}$

Corresponding author : Chan Sup Shim Digestive Disease Center, Department of Internal Medicine, Konkuk University Medical Center, Konkuk University School of Medicine, 120-1 Neungdong-ro, Gwangjin-gu, Seoul 05030, Korea

Tel. +82-2-2030-8195 Fax. +82-2-2030-5029

E-mail; chansshim@naver.com

ORCID: https://orcid.org/0000-0002-3300-1417

Keywords: Endoscopic Ultrasound-Guided Fine Needle Aspiration, Metal stent, Drainage

This is an Open Access article distributed under the terms of the Creative Commons Attribution Non-Commercial License (http:// creativecommons.org/licenses/by-nc/3.0/) which permits unrestricted non-commercial use, distribution, and reproduction in any medium, provided the original work is properly cited.

Copyright $\odot 2018$ by The Korean Journal of Pancreas and Biliary Tract 


\section{INTRODUCTION}

Peripancreatic fluid collection requires drainage when symptomatic. The management of symptomatic peripancreatic fluid includes endoscopic, surgical, and percutaneous approaches. ${ }^{1}$ Endoscopic ultrasonography (EUS)-guided drainage has been used widely as first-line therapy to manage collected pancreatic fluid using a plastic or metal stent. Although double-pigtail plastic stents have been the mainstay of therapy, they can become occluded easily because of their small caliber when secondary infection occurs, increasing the need for re-intervention. ${ }^{2}$

Fully covered self-expanding metal stents (FCSEMSs) have been used to overcome these limitations, but conventional FCSEMSs can still migrate or leak, leading to serious adverse events. ${ }^{3}$ Therefore, specially designed lumen-apposing metal stents with flared ends have been proposed, and several novel lumen-apposing metal stents have been reported on previously. ${ }^{3,4}$ We evaluated the technical and clinical outcomes, safety, and removability of a newly developed biflanged tubulartype FCSEMS with a conventional stent delivery system in an animal study and clinical application.

\section{METHODS}

Six patients underwent endoscopic treatment using the new FCSEMS between January 2013 and July 2016. One female dog was used for the animal study. The biflanged FCSEMS (EGIS S-PD stent; S\&G Biotech Inc., Seongnam, Korea) was made of nitinol wire and was covered fully with a silicone membrane. The diameter of the flange was $20 \mathrm{~mm}$ at both ends to provide stability and minimize migration risk. The stent was available in a $10-\mathrm{mm}$ diameter with lengths of 2,3 , and $4 \mathrm{~cm}$ (Fig. 1). The shoulder is rounded to minimize trauma, and the enteric end has a retrieval suture. This stent is deployed with a $10 \mathrm{~F}$ conventional delivery system, so that it can be inserted with an endoscope.

All procedures were performed with patients under conscious sedation with midazolam and pethidine hydrochloride. Two experienced endoscopists Chan Sup Shim and Young
Koog Cheon inserted the stents using a conventional linear echoendoscope (GF-UCT140; Olympus Medical, Tokyo, Japan). EUS-guided transgastric puncture was performed using a 19-gauge needle (Echotip-19; Cook Medical, Winston-Salem, NC, USA), followed by placement of a 0.035 -inch guidewire. The puncture site was dilated over the wire using a Bougie dilator (6F-8F Soehendra dilator; Cook Medical) or a needletype sphincterotome (Fusion Needle Knife; Cook Medical). After the tract was dilated, a balloon catheter (4-mm Hurricane; Boston Scientific, Natick, MA, USA) was used to achieve sufficient dilation. The stent delivery system was inserted over the guidewire and advanced into the pancreatic fluid, and the stent was deployed (Fig. 2). After complete delivery, the stent lumen was dilated up to 8 or $10 \mathrm{~mm}$ with a balloon catheter (Hurricane; Boston Scientific) to achieve complete apposition, if needed. Antibiotics were given intravenously before and after the procedure. Subjects fasted until the morning after the procedure, and oral intake was restarted unless the patients were in pain and had complications. The volume of fluid that collected was evaluated by periodic computed tomography (CT) scans performed after the procedure until shrinkage. The stents were removed endoscopically after the pancreatic fluid disappeared completely, as confirmed by CT. Follow-up CT was performed 2 months after stent removal. The clinical success rate, complications, and removability were evaluated. Technical success was defined as correct placement of the FCSEMS. Clinical success was defined as complete resolution of the pancreatic fluid collection or infection without surgical treatment. All patients provided

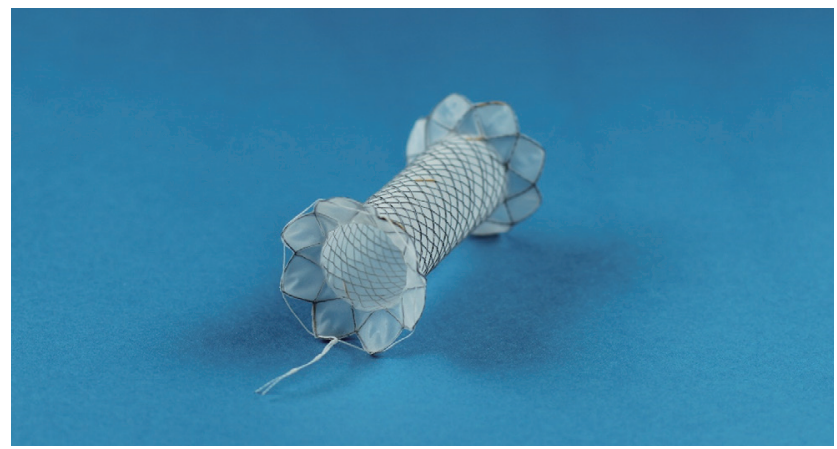

Fig. 1. A new fully covered metal stent with folding-back wide anchoring flanges for lumen apposition. 
written informed consent, and our institutional review board approved the study (KUH1010675).

A cholecystogastrostomy tract was made under EUS guidance for the animal study, and the stent was deployed across the lumen under fluoroscopic and endoscopic guidance. Contrast was injected into the gallbladder through the stent to confirm the absence of leakage. Necropsy was performed immediately to check the cholecystoduodenal tract. The animal ethics committee in institutional review board approved the study (KUH1011611).

\section{RESULTS}

Six patients (four men and two women; mean age, 52 years) underwent EUS-guided stent placement between October
2012 and May 2016 due to pancreatic fluid collection (five cases of pancreatic pseudocysts and one case of walled-off necrosis) 13-39 days after the onset of pancreatitis. Disconnected duct syndrome was suspected in one of the six cases.

The FCSEMSs were deployed successfully and expanded fully in all six (100\%) cases. No complication was observed during the procedure. In one patient with walled-off necrosis, direct endoscopic necrosectomy was performed with a therapeutic endoscope. We did not observe the insides of the cysts in the cases of pancreatic pseudocyst.

Clinical success was achieved in five $(83.3 \%)$ cases. The pancreatic pseudocysts were drained successfully without direct endoscopic necrosectomy in all five (100\%) cases (Fig. 2). Direct endoscopic necrosectomy could not be completed in the case of walled-off necrosis because the patient
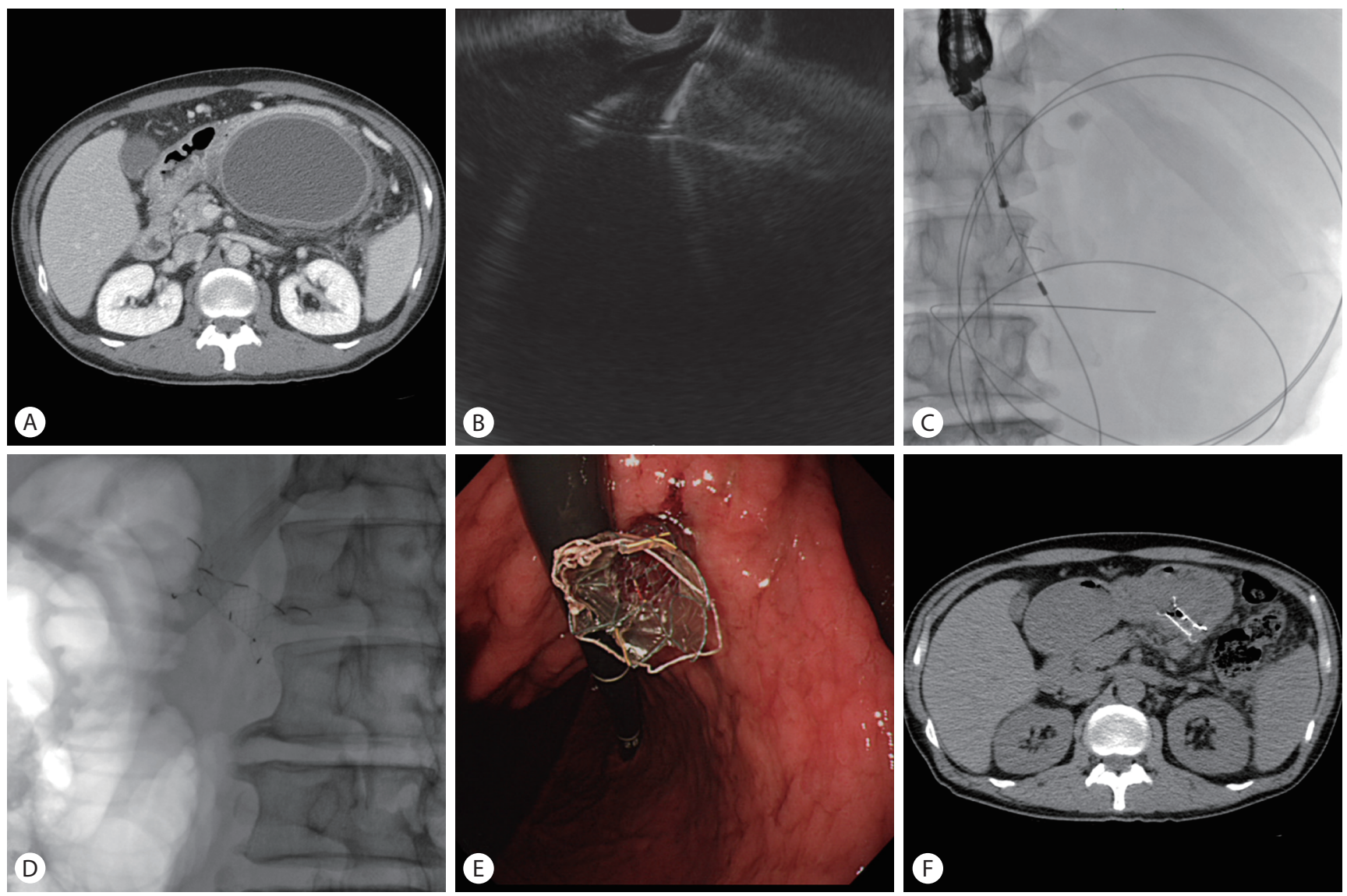

Fig. 2. (A) Abdominal computed tomography (CT) scan showing a huge pancreatic pseudocyst. (B) Endoscopic ultrasound (EUS) image showing puncturing of a pseudocyst with a 19-gauge needle. (C) The metal stent was inserted into pseudocyst through the EUS working channel. (D) Plain abdominal X-ray showing fully deployed stent. (E) Endoscopic view of the deployed stent. (F) CT image showing complete resolution of the pancreatic pseudocyst after drainage with the stent 1 month after the procedure. 
developed septic shock after the first session (Fig. 3). This patient was transferred to another hospital at his request. Otherwise, no early complication was observed, and no stent migrated in any patient. The FCSEMSs were removed with no complication in the five $(83.3 \%)$ cases in which removal was attempted, 19-50 days after insertion.

The stent was deployed successfully in the gallbladder lumen through the duodenal wall in one dog. The duodenum and gallbladder lumen were connected completely without contrast leakage. No complication was observed during the procedure. A necropsy performed immediately after the procedure showed that the cholecystoduodenal tract was intact (Fig. 4).

\section{DISCUSSION}

Plastic stent placement to treat peripancreatic fluid collection has been the standard treatment, but drainage is frequently suboptimal. ${ }^{5}$ Small-diameter stents may cause ineffective drainage or superinfections of the peripancreatic fluid, which typically occurs when the stents become obstructed. ${ }^{6}$ Therefore, repeat stent changes with multiple stents are needed for adequate drainage/debridement.

Conventional FCSEMSs (biliary or esophageal) have been used with some success and have several merits over plastic stents, such as a larger diameter for longer patency, obviating the need for multiple plastic stents. In a large retrospective study of patients with peripancreatic fluid and pancreatic
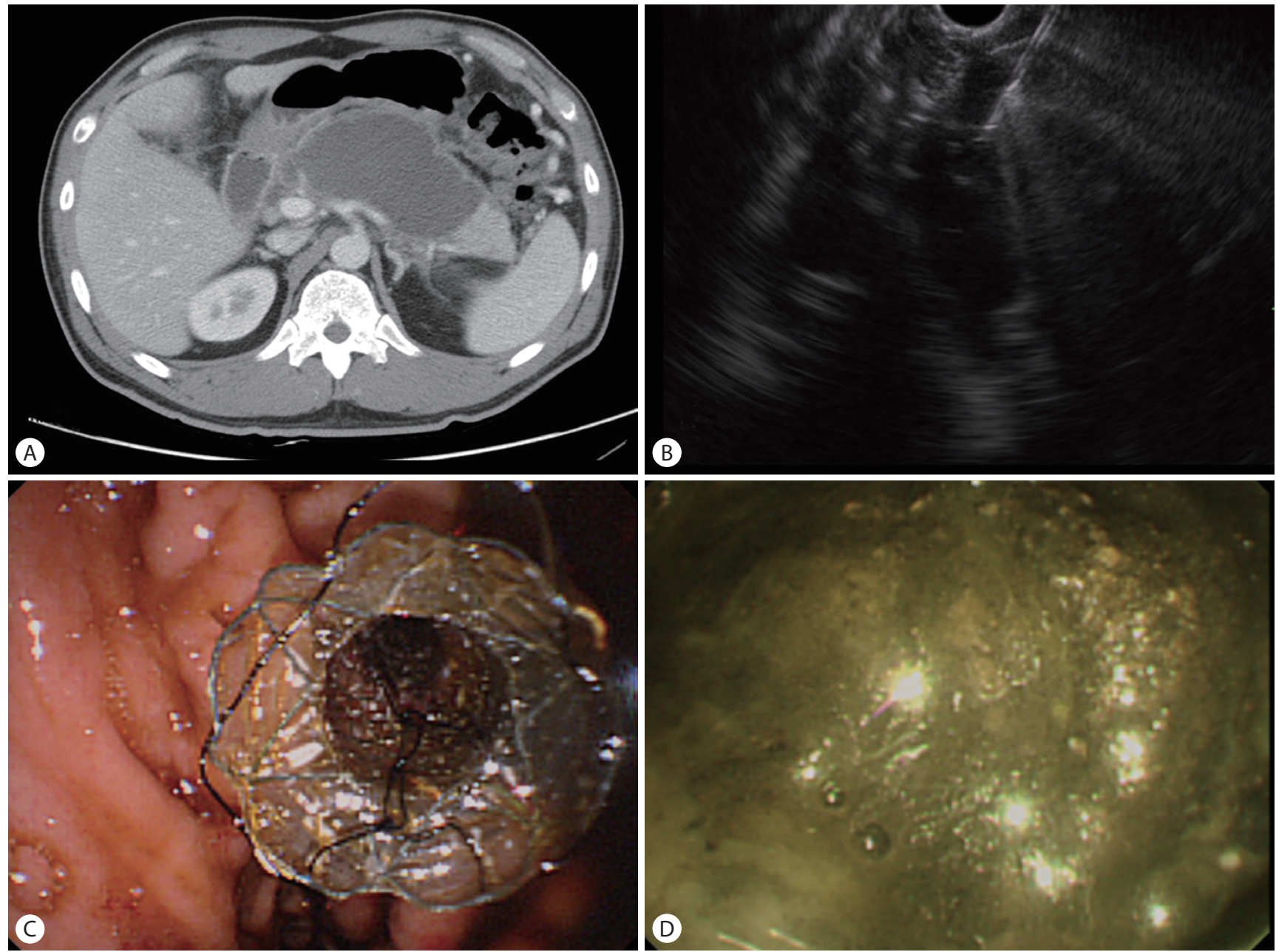

Fig. 3. (A) Abdominal computed tomography scan showing walled-off necrosis. (B) Endoscopic ultrasound image showing puncturing of the walled-off necrosis with a 19-gauge needle. (C) Endoscopic view of the fully deployed stent in the stomach. (D) Endoscopic view showing necrosis in the stent. 
pseudocysts, EUS-guided drainage using FCSEMSs improved the pseudocyst complete resolution rate ( $98 \%$ vs. $89 \%$, $p=0.01)$ and decreased the adverse event rate (16\% vs. $31 \%$, $p=0.006)$ compared with the use of plastic stents. ${ }^{7}$ In a prospective comparative study, the median procedure time for FCSEMS use was significantly shorter than that for plastic stent use (15.0 vs. 29.5 min, $p<0.01$ ). ${ }^{6}$ However, conventional FCSEMS has several disadvantages, including the risk of stent migration and abutment of the end of the stent against the luminal wall, which may cause bleeding and tissue injury. ${ }^{1}$

Specially designed lumen-apposing metal stents, such as the AXIOS (Boston Scientific) and SPAXUS and Nagi (Taewoong Medical, Goyang, Korea) stents, which have wide flares at both ends to prevent migration, have demonstrated high efficacy and safety. ${ }^{3,4,8}$ These devices have wide diameters (10-16 $\mathrm{mm}$ ) and short lengths, and their wide flanges can actively hold peripancreatic fluid in the lumen. Large clinical studies have demonstrated high technical and clinical success rates (89-98\%), defined as resolution of clinical symptoms with a decrease in peripancreatic fluid to $\leq 2 \mathrm{~cm}$ on imaging $(81-100 \%){ }^{1,8,9}$ Several cohort studies have indicated that lumen-apposing metal stents use may decrease the need for repeat procedures, total adverse events, salvage surgery, and length of hospital stay when compared with plastic stents for use in complicated fluid collections and walled-off necrosis. ${ }^{1,5,10}$

However, in a recent randomized trial, serious adverse events occurred in patients with peripancreatic fluid treated with lumen-apposing metal stents. ${ }^{11}$ Stent-related adverse events were observed in 6 of 12 patients randomized to treatment with lumen-apposing metal stents (delayed bleeding in 3 patients, buried stent syndrome in 2, and obstructive jaundice in 1 patient), compared with 0 of 9 patients in the plastic stent cohort. Rapid decompression of the walled-off necrosis facilitated by the wide-bore metal stent may lead to the stent impinging on the internal wall of the collection cavity resulting in damage to adjacent vessels, causing bleeding, or inward migration of the outer flange of the stent causing buried stent syndrome. Similarly, in a recent retrospective study of patients undergoing drainage of pancreatic pseudocysts or walled-off necrosis $(n=149)$, patients with lumen-apposing metal stents had a higher risk of pseudoaneurysm bleeding than patients with double pig-tail plastic stents (OR, 10.0; 95\% CI, 1.19-84.6; $p=0.009)$. ${ }^{12}$ Therefore newly designed stent is needed to overcome bleeding risk with lumen-apposing metal stents, migration risk with conventional FCSEMS, and higher infection and reintervention rates with plastic stents.

We investigated the use of a new tubular-type FCSEMS with wide flanges for endoscopic treatment of pancreatic fluid. The new FCSEMS has wide anchoring flanges at both ends to prevent migration, so no additional double pig-tail plastic stent placement is needed to anchor the FCSEMS. Although it has tubular design, the wide flanges may generate enough anchoring forces between the cyst and the enteral
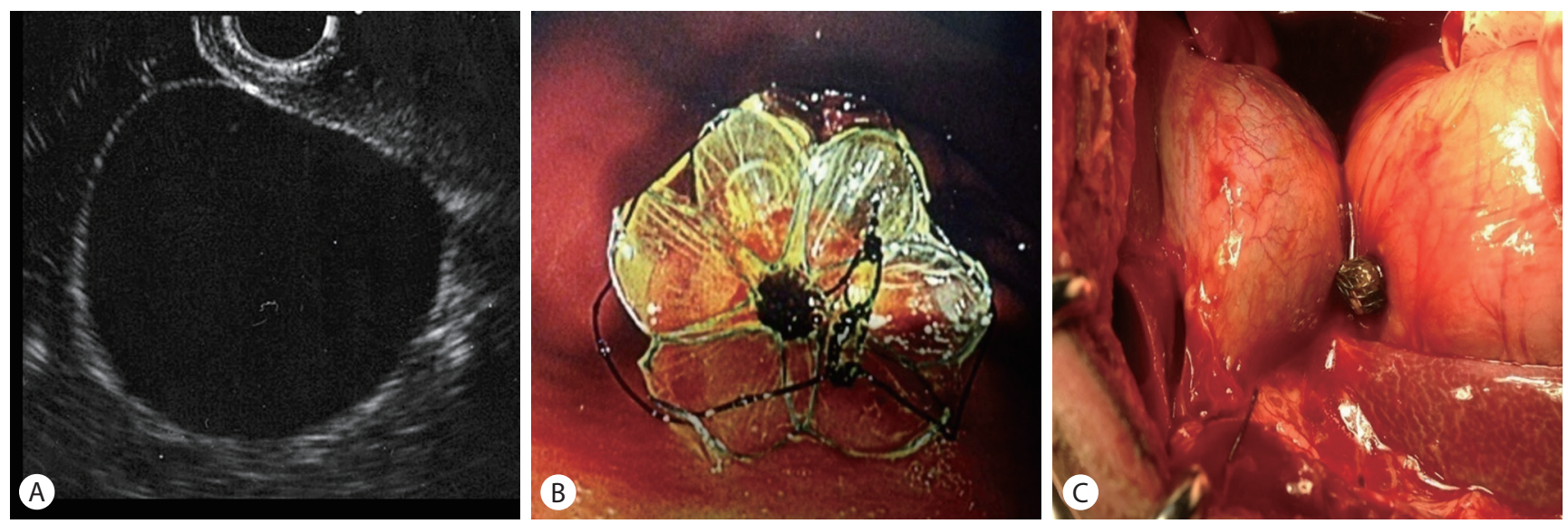

Fig. 4. Endoscopic ultrasound (EUS)-guided gallbladder drainage in a dog. (A) The gallbladder was visualized by EUS. (B) A metal stent was placed in the gallbladder via the transduodenal route. (C) The duodenum and gallbladder lumen were connected completely on necropsy. 
lumen, thus preventing to risk of stent migration and fluid leakage. Unlike the short $(1 \mathrm{~cm})$ and immobile lumen-apposing metal stents, our FCSEMS are longer $(\geq 2 \mathrm{~cm})$ and relatively mobile due to its tubular design. These features may decrease the risk of bleeding and buried stent syndrome. In this study, the new FCSEMS was inserted and expanded successfully in all cases, and no stent migrated or caused bleeding. The animal study also demonstrated that the new stent deployed easily under EUS, resulting in complete fusion of the duodenal and gallbladder walls like a single organ with no leakage. The new FCSEMS also had a wide lumen, and thin delivery system. Therefore, the stent was inserted without the need to change to an endoscope with a larger channel diameter.

This study has several limitations. It was a retrospective study involving a small case series. The follow-up duration was short, so recurrence and other complications might have been underestimated. In conclusion, endoscopic treatment using a new biflanged tubular-type FCSEMS was effective and safe for the treatment of pancreatic fluid collection.

\section{요 약}

배경목적: 내시경 초음파 유도하 췌장 저류액 배액은 효과적인 시술이나이 시술에 특화된 맞춤형 부속기구는 부족한 실정이다. 이 연구의 목적은 내시경 초음파 유도하 경위장관 배액술 전용으로 새로 고안된 양측 플랜지가 있는 완전피막형 금속 스텐트의 유용성을 평가하고자 하였다.

방법: 동물연구는 한 마리의 개를 대상으로 하였고 임상연 구는 췌장 저류액을 가진 5 명의 환자 (5명은 췌장가성낭종, 1 명은 벽 형성 췌장괴사)를 대상으로 하여 내시경 초음파 유도하 배액술을 시행하였다. 연구의 성과는 기술적, 임상적 성공여부, 합병증, 스텐트 제거 가능 여부로 판단하였다.

결과: 동물연구에서 스텐트는 내시경 초음파 유도하 경십 이지장 접근으로 합병증 없이 성공적으로 유치되었다. 시술 직후 시행한 부검에서 담낭-십이지장 연결은 온전하였다. 6명의 환자에서 모두 스텐트는 성공적으로 유치되었다. 모든 환자에서 시술후 합병증과 스텐트 이탈은 없었다.

결론: 새로 고안된양측플랜지가 있는완전피막형 금속스텐트를 사용한 췌장저류액의 내시경 초음파 유도하 경위장관 배액술은 기술적으로 가능하였고 심각한 합병증은 없었다. 스텐트
선단부의 맞춤형 플랜지 형상은 시술의 효과를 배가시켰다.

국문 색인: 내시경 초음파 유도하 세침흡인술, 금속스텐트, 배액

\section{Conflicts of Interest}

The authors have no conflicts to disclose.

\section{REFERENCES}

1. Siddiqui $A A$, Kowalski $T E$, Loren $D E$, et al. Fully covered self-expanding metal stents versus lumen-apposing fully covered self-expanding metal stent versus plastic stents for endoscopic drainage of pancreatic walled-off necrosis: clinical outcomes and success. Gastrointest Endosc 2017:85:758-765

2. Lee HS, Chung MJ. Past, present, and future of gastrointestinal stents: new endoscopic ultrasonography-guided metal stents and future developments. Clin Endosc 2016;49:131-138.

3. Moon JH, Choi HJ, Kim DC, et al. A newly designed fully covered metal stent for lumen apposition in EUS-guided drainage and access: a feasibility study (with videos). Gastrointest Endosc 2014;79:990-995.

4. Yamamoto $\mathrm{N}$, Isayama $\mathrm{H}$, Kawakami $\mathrm{H}$, et al. Preliminary report on a new, fully covered, metal stent designed for the treatment of pancreatic fluid collections. Gastrointest Endosc 2013;77:809-814.

5. Bapaye A, Dubale NA, Sheth KA, et al. Endoscopic ultrasonographyguided transmural drainage of walled-off pancreatic necrosis: comparison between a specially designed fully covered bi-flanged metal stent and multiple plastic stents. Dig Endosc 2017;29:104-110.

6. Lee BU, Song TJ, Lee SS, et al. Newly designed, fully covered metal stents for endoscopic ultrasound (EUS)-guided transmural drainage of peripancreatic fluid collections: a prospective randomized study. Endoscopy 2014;46:1078-1084.

7. Sharaiha RZ, Defilippis EM, Kedia P, et al. Metal versus plastic for pancreatic pseudocyst drainage: clinical outcomes and success. Gastrointest Endosc 2015;82:822-827.

8. Walter D, Will U, Sanchez-Yague A, et al. A novel lumen-apposing metal stent for endoscopic ultrasound-guided drainage of pancreatic fluid collections: a prospective cohort study. Endoscopy 2015;47:63-67.

9. Shah RJ, Shah JN, Waxman I, et al. Safety and efficacy of endoscopic ultrasound-guided drainage of pancreatic fluid collections with lumenapposing covered self-expanding metal stents. Clin Gastroenterol Hepatol 2015;13:747-752.

10. Mukai S, Itoi T, Baron TH, et al. Endoscopic ultrasound-guided placement of plastic vs. biflanged metal stents for therapy of walled-off necrosis: a retrospective single-center series. Endoscopy 2015;47:47-55.

11. Bang JY, Hasan M, Navaneethan U, Hawes R, Varadarajulu S. Lumenapposing metal stents (LAMS) for pancreatic fluid collection (PFC) drainage: may not be business as usual. Gut 2017;66:2054-2056.

12. Brimhall B, Han S, Tatman PD, et al. Increased incidence of pseudoaneurysm bleeding with lumen-apposing metal stents compared to double-pigtail plastic stents in patients with peripancreatic fluid collections. Clin Gastroenterol Hepatol 2018;16:1521-1528. 